\title{
APOLOGIES AND ACKNOWLEDGEMENTS
}

Ladies and Gentlemen: We have reached the end of our Symposium proceedings and allow me to have the final word.

Mr E T Matenge, Director of National Parks of the Republic of Botswana, as well as Mr A B Bridgens, Secretary-General of SARCCUS (Southern African Regional Commission for the Conservation and Utilization of the Soil) have tended their apologies for absence.

I would like to thank the Cabinet (in particular The Hon. Min. H Schoeman) for the announcement of the institution of the 10th National Park. This gratitude not only comes from the officials of the National Parks Board, but also from the people of the entire RSA, be they white, brown or black. I also thank my Board for permission to go ahead with the arrangements for this Symposium. The person who had to bite the bit was Dr G de Graaff and with the aid of his colleagues, everything ran smoothly. These efforts are greatly appreciated.

Furthermore, I would like to thank the International Conference Organisers. Their loudspeakers and translation system never let us down. We had a large group of donours, financially and otherwise. These include the Rembrandt Organisation, the Rennies Organisation, Coca-Cola International, the United Tobacco Company, Mr and Mrs Dingler, Winter Minerals (Nelspruit) and the Total Petroleum Company. To these organizations and individuals our thanks are due.

Without becoming sentimental, it is to be emphasized that no Symposium can be held without people willing to participate. I would like to thank every speaker, especially Dr F Vollmar, who came all the way from Switzerland to open this Symposium. The reaction of the audience was wonderful. In particular I would also like to thank His Royal Highness, Prince M. Dlamini (Swaziland) as well as the many leaders representing the developing territories, for their esteemed presence. My thanks are also due to the South African Broadcasting Corporation.

We hope that whatever was summarized in such an efficient way by Dr Martiny, that it is clear that this Symposium emphasized the importance of education and carried a message directed at the youth of Southern Africa.

R. Knobel

Symposium Chairman 